\title{
Correlation between participation in physical activity and healthy nutrition: An example of a sports science faculty
}

Authors' Contribution: A Study Design B Data Collection C Statistical Analysis D Data Interpretation E Manuscript Preparation F Literature Search G Funds Collection

\author{
Yasemin Arı ${ }^{\text {ABCDEF, Ergün Çakır }{ }^{2} \text { ADEF }}$ \\ ${ }^{1}$ Tekirdağ Namık Kemal University, School of Physical Education and Sports, \\ Tekirdağ, Turkey \\ 2 Van Yüzüncü Yıl University, School of Physical Education and Sports, Van, Turkey
}

\section{abstract}

Background:

Material and methods:

It is important to encourage people to participate in physical activities and to develop motivational approaches to healthy nutrition in order to maintain a healthy life. This study was conducted to examine the relationship between the physical activity levels of university students and their attitudes to healthy nutrition. the sports sciences department in terms of gender, smoking and regular exercise variables, a statistically significant difference was found in the level of participation in physical activity in the variable of meals consumed during the day. A positive significant relationship was found between the participants' attitude towards healthy nutrition and their level of participation in physical activity.

Conclusions: It was determined that students with high participation in physical activity also have high attitudes towards healthy nutrition.

Key words: physical activity, healthy nutrition, student, health-related behavior.

\section{article details}

Article statistics: Word count: 3,069; Tables: 9; Figures: 0; References: 33

Received: March 2021; Accepted: April 2021; Published: September 2021

Full-text PDF: http://www.balticsportscience.com

Copyright @ Gdansk University of Physical Education and Sport, Poland

Indexation: Celdes, Clarivate Analytics Emerging Sources Citation Index (ESCI), CNKI Scholar (China National Knowledge Infrastructure), CNPIEC, DOAJ, EBSCO - Central \& Eastern European Academic Source, EBSCO - SPORTDiscus, EBSCO Discovery Service, Google Scholar, Index Copernicus, J-Gate, Naviga (Softweco, Primo Central (ExLibris), ProQuest - Family Health, ProQuest - Health \& Medical Complete, ProQuest - Illustrata: Health Sciences, ProQuest Nursing \& Allied Health Source, Summon (Serials Solutions/ProQuest, TDOne (TDNet), Ulrich's Periodicals Directory/ ulrichsweb, WorldCat (OCLC)

Funding: This research received no specific grant from any funding agency in the public, commercial, or not-for-profit sectors.

Conflict of interests: Corresponding author:

Open Access License: Authors have declared that no competing interest exists.

Yasemin Arı, School of Physical Education and Sports, Tekirdağ Namık Kemal University, Tekirdağ, Turkey; telephone: +90 282250 3213; e-mail: yari@nku.edu.tr

This is an open access article distributed under the terms of the Creative Commons Attribution-Non-Commercial-NoDerivatives 4.0 International (https://creativecommons.org/licenses/by-nc-nd/4.0/), which permits use, distribution, and reproduction in any medium, provided the original work is properly cited, the use is non-commercial and is otherwise in compliance with the license. 


\section{INTRODUCTION}

Physical activity emerges as an important component that supports the physiological, emotional, social, motor and mental development of an individual, providing energy balance and healthy life with the implementation of movements in a certain order. In this sense, the importance of physical activity is to save the individual from a sedentary life and prevent psychological, physiological and social disorders caused by this lifestyle $[1,2]$.

Regular physical activity helps a person to get rid of the stagnant life and maintain the diet. A good diet helps individuals to continue their lives in a healthier way and to perform vital functions in the best way [3].

Individuals who do not exercise regularly and do not participate in physical activity have a higher rate of body fat, growth and developmental retardation, iron deficiency anemia, and a decrease in academic achievement; therefore, it is known that physical and psychological problems are more common in these individuals [4].

It is important to be able to minimize health risks in order to live and age healthily. In order to achieve this, healthy nutrition and physical activity should be increased. Nowadays, with the effect of increasing urbanization with industrialization, people have become unable to do regular physical activity, and disorders have been observed in healthy nutrition habits. People should consume nutrients in the right amounts, at the right times and consciously in order to protect their health and improve it. Nutrition habit is one of the factors that directly affect human health. Irregular nutrition habits increase the possibility of developing diseases such as obesity, cardiovascular diseases, hypertension and diabetes. For this reason, balanced and adequate nutrition has an important effect on preventing diseases caused by irregular nutrition behaviors that endanger human life $[5,6]$.

The relationship between physical activity and nutrition needs to be well adjusted for a healthy body. Based on this information, this study aimed to determine and evaluate the relationship between participation in physical activity and healthy nutrition of people who are educated in the field of sports sciences.

\section{MATERIAL AND METHODS}

\section{Research Model and Sample Group}

The research was designed in a scanning model, one of the quantitative research methods. The scanning model is expressed as studies in which the participants' skills, ability, opinions, interests or attitudes towards a subject are measured and conducted on a larger number of participants [7].

The research group consists of 392 volunteer students, 153 females and 239 males, studying at Tekirdağ Namık Kemal University School of Physical Education and Sports. The study was approved by the local university ethics committee (Date: 18.09.2020, Number: E.47700, Meeting number: T2020-500).

\section{Data Collection}

Due to the Covid-19 outbreak, the group participated in the research in scattered places so the scale form was sent to students studying in sports sciences via e-questionnaire and e-mail in order to facilitate access for the participants. A total of 392 students voluntarily participated in the study by completing the scale form by e-mail. Personal information form, International Physical Activity Questionnaire-Short Form (IPAQ-SF) and Attitude Scale for Healthy Nutrition (ASHN) were used in the research. 
The personal information form provides information about the participants' gender, age, BMI, regular exercise status, smoking and the number of meals consumed during the day.

The short form of the International Physical Activity Questionnaire (IPAQ) was used to evaluate the participation of physical education students in physical activity [8]. The validity and reliability of the survey in Turkey was conducted in 2005 by Öztürk [9]. In the study, the short form of the questionnaire, which can be applied on its own and includes one previous week, was used to evaluate the level of physical activity. This questionnaire includes questions about physical activity (PA) performed for at least 10 minutes in the last 7 days. The questionnaire determines how many days in the last week and how long for each day a person participated in: a) heavy-intensity physical activities (HPA), b) medium-intensity physical activities (MPA), c) walking (W). In the last question, the time spent daily without moving (sitting, lying down, etc.) is determined. The MET method is used to determine the level of physical activity. $1 \mathrm{MET}=3.5 \mathrm{ml} / \mathrm{kg} / \mathrm{min}$. At rest, each person consumes $3.5 \mathrm{ml}$ of oxygen per kilogram per minute. In IPAQ, it is accepted that $\mathrm{HPA}=8.0 \mathrm{MET}, \mathrm{MPA}=4.0 \mathrm{MET}, \mathrm{W}=3.3 \mathrm{MET}$. The total amount of MET spent on these three different physical activities is calculated by determining how many days and for how long each person performs HPA, MPA and W in a week. An example is given in Table 1.

Table 1. Determination of PA levels by the MET method

\begin{tabular}{ccccc} 
Physical Activity Type & Met & 1 day / minute & Week / day & Total \\
\hline Walk & 3.3 & 30 & 5 & 495 MET-min/week \\
MPA & 4.0 & 40 & 4 & 640 MET-min/week \\
HPA & 8.0 & 30 & 3 & 720 MET-min/week \\
TOTAL & & & 1855METmin/week \\
\hline
\end{tabular}

Physical Activity level is determined in 3 categories.

Category I: Inactive ones: <600 MET-min / week

II category: Minimum active ones: >600-3000 MET-min / week

III category: HPA active: <3000 MET-min / week

The other scale used in the study was the Attitude Scale for Healthy Nutrition (ASHN) developed by Tekkurşun Demir and Cicioğlu (2019) [10]. ASHN has a structure consisting of 21 items and 4 factors. These factors are named Nutrition Information (NI), Nutritional Emotion (NE), Positive Nutrition (PN), and Malnutrition (M). The lowest score that can be obtained from the scale is 21 and the highest score is 105. It is explained that the participants having 21 points from the ASHN have a very low attitude, 23-42 points - low attitude, 43-63 points -medium, 64-84 points - high and 85-105 points - an ideally high attitude to healthy nutrition. The ratings of the positive items in the scale are "Absolutely Disagree", "Disagree", "Undecided", "Agree", and "Strongly Agree". Positive attitude items were scored as 1, 2, 3, 4 and 5, while negative attitude items were scored as 5, 4, 3, 2 and 1 .

\section{Statistical Analysis}

All statistical analyses were performed using SPSS version 18.0 software (Statistics Package for Social Sciences; SPSS Inc., Chicago, IL, USA). It was determined that all data showed normal distribution (Kurtosis and Skewness values $-1.5,+1.5$ ) [11]. At this point, independent samples t test was used to compare two variables. One-way analysis of variance was used to compare more than two variables. Post hoc analyses were made by using the Tukey test. Effect dimensions (Cohen's d) were calculated for the significance of comparisons. Thresholds for effect size statistics are as follows: $<0.20=$ unimportant, $0.20-0.59$ small, $0.6-1.19=$ medium, $1.2-1.99=$ large, $\geq 2.0$ very large [12]. Results are presented as mean \pm standard deviation and 0.05 was considered statistically significant for all analyses. 


\section{RESULTS}

Descriptive statistics of students studying at Tekirdağ Namık Kemal University in the 2020-2021 academic year who participated in the study are shown in Table 2. Table 3. shows statistics of scale and sub-dimension score

Table 2. Demographic characteristics of the participants

\begin{tabular}{|c|c|c|c|c|c|}
\hline \multirow[t]{2}{*}{ Personal characteristics } & Explanation & \multicolumn{2}{|c|}{ Woman } & \multicolumn{2}{|c|}{ Male } \\
\hline & $\mathrm{N}$ & \multicolumn{2}{|c|}{153} & \multicolumn{2}{|c|}{239} \\
\hline & Mean \pm SD & \multicolumn{2}{|c|}{$20.21 \pm 1.81$} & \multicolumn{2}{|c|}{$20.99 \pm 2.18$} \\
\hline \multirow[t]{3}{*}{ Age (years) } & Median & \multicolumn{2}{|c|}{20} & \multicolumn{2}{|c|}{21} \\
\hline & Min-Max & \multicolumn{2}{|c|}{$18-28$} & \multicolumn{2}{|c|}{$18-35$} \\
\hline & Mean \pm SD & \multicolumn{2}{|c|}{$22.97 \pm .02$} & \multicolumn{2}{|c|}{$22.98 \pm .02$} \\
\hline \multirow[t]{3}{*}{ BMI } & Median & \multicolumn{2}{|c|}{20.54} & \multicolumn{2}{|c|}{22.72} \\
\hline & Min-Max & \multicolumn{2}{|c|}{$15.62-21.70$} & \multicolumn{2}{|c|}{$17.24-33.50$} \\
\hline & & $\mathrm{N}$ & $\%$ & $\mathrm{~N}$ & $\%$ \\
\hline \multirow{2}{*}{ Do you exercise regularly? } & Yes & 88 & 57.5 & 161 & 67.4 \\
\hline & No & 65 & 42.5 & 78 & 32.6 \\
\hline \multirow{2}{*}{ Do you smoke? } & Yes & 47 & 30.7 & 69 & 28.9 \\
\hline & No & 106 & 69.3 & 170 & 71.1 \\
\hline \multirow{4}{*}{$\begin{array}{l}\text { How many meals do you } \\
\text { consume during the day? }\end{array}$} & 2 & 46 & 30.1 & 47 & 19.7 \\
\hline & 3 & 90 & 58.8 & 139 & 58.2 \\
\hline & 4 & 12 & 7.8 & 39 & 16.3 \\
\hline & 5 and above & 5 & 3.3 & 14 & 5.9 \\
\hline
\end{tabular}

N: Number; M: Mean; SD: Standard deviation; Min: Minimum; Max: Maximum; BMI: Body Mass Index

Table 3. Descriptive statistics of scale and sub-dimension scores

\begin{tabular}{lccccc} 
Scale and Sub-Dimensions & $\mathrm{N}$ & Mean & SD & Skewness & Kurtosis \\
\hline Attitude Scale for Healthy Nutrition & 392 & 75.50 & 12.08 & .076 & -.706 \\
Information about nutrition & 392 & 3.87 & 1.16 & -1.403 & 1.082 \\
Feeling for nourishment & 392 & 3.17 & .86 & .065 & -.470 \\
Positive nutrition & 392 & 3.50 & 1.10 & -.732 & -.254 \\
Malnutrition & 392 & 3.91 & .044 & -.886 & .456 \\
Total Physical Activity & 392 & 2921.90 & 1902.82 & .665 & .111 \\
Walk & 392 & 981.69 & 927.48 & 1.430 & 1.201 \\
Medium-intensity physical activities (MPA) & 392 & 406.99 & 430.76 & 1.299 & 1.311 \\
Heavy physical activities (HPA) & 392 & 1528.16 & 1582.28 & 1.251 & 1.200 \\
\hline
\end{tabular}

N: Number; M: Mean; SD: Standard deviation

In order to determine whether the mean scores of IPAQ and the Attitude Scale for Healthy Nutrition and its sub-dimensions show normal distribution, skewness and kurtosis values were taken into consideration. Accordingly, it was determined that all data showed normal distribution (Kurtosis and Skewness values $-1.5,+1.5$ ).

According to Table 4, the fact that the internal consistency coefficients of the attitude scale for healthy nutrition and its sub-dimensions are .70 and higher is considered sufficient for the reliability of the test scores. With these findings, it was concluded that the data on the attitude scale for healthy nutrition are reliable [13]. 
Table 4. Internal consistency coefficient of attitude scale for healthy nutrition $(\alpha)$

\begin{tabular}{lcc}
\multicolumn{1}{c}{ ASHN and sub-dimensions } & Number of items & Cronbach alpha $(\alpha)$ \\
\hline Attitude scale for healthy nutrition & 21 & .824 \\
Information about nutrition & 5 & .971 \\
Feeling for nourishment & 6 & .784 \\
Positive nutrition & 5 & .894 \\
Malnutrition & 5 & .840 \\
\hline
\end{tabular}

Table 5. Comparison of the ASHN and IPAQ scales according to gender

\begin{tabular}{|c|c|c|c|c|c|c|c|c|c|}
\hline Scale & Variable & $\mathrm{N}$ & M & SD & $f$ & $\mathrm{t}$ & $d f$ & $p$ & $\eta^{2}$ \\
\hline \multirow{2}{*}{ ASHN } & Woman & 153 & 77.03 & 12.53 & \multirow{2}{*}{.060} & \multirow{2}{*}{2.026} & \multirow{2}{*}{390} & \multirow{2}{*}{$.043 *$} & \multirow{2}{*}{.207} \\
\hline & Male & 239 & 74.51 & 11.70 & & & & & \\
\hline \multirow{2}{*}{ IPAQ } & Woman & 153 & 2486.10 & 1861.27 & \multirow{2}{*}{.155} & \multirow{2}{*}{-3.686} & \multirow{2}{*}{390} & \multirow{2}{*}{$.000 *$} & \multirow{2}{*}{.382} \\
\hline & Male & 239 & 3200.87 & 1880.32 & & & & & \\
\hline
\end{tabular}

$* p<0.05$

As shown in Table 5, a significant difference was found in the comparison of the gender variable of sports science students in terms of participation in physical activity and attitudes to healthy nutrition $(\mathrm{p}<0.05)$. When the effect size value was examined, it was determined that participation in physical activity $\left(\eta^{2}=.382\right)$ and attitudes to healthy nutrition $\left(\eta^{2}=.207\right)$ had a small effect on female and male participants.

Table 6. Comparison of the ASHN and IPAQ scales in terms of the variable smoking

\begin{tabular}{|c|c|c|c|c|c|c|c|c|c|}
\hline Scale & Variable & $\mathrm{N}$ & $M$ & SD & $f$ & $\mathrm{t}$ & $d f$ & $\mathrm{p}$ & $\eta^{2}$ \\
\hline \multirow{2}{*}{ ASHN } & Yes & 116 & 72.47 & 12.14 & \multirow{2}{*}{.897} & \multirow{2}{*}{-3.253} & \multirow{2}{*}{390} & \multirow{2}{*}{$.001^{*}$} & \multirow{2}{*}{.358} \\
\hline & No & 276 & 76.77 & 11.85 & & & & & \\
\hline \multirow{2}{*}{ IPAQ } & Yes & 116 & 2573.54 & 1781.72 & \multirow{2}{*}{.879} & \multirow{2}{*}{-2.364} & \multirow{2}{*}{390} & \multirow{2}{*}{$.019 *$} & \multirow{2}{*}{.265} \\
\hline & No & 276 & 3068.30 & 1935.92 & & & & & \\
\hline
\end{tabular}

$* p<0.05$

According to Table 6, a significant difference was found in the comparison of participation in physical activity and attitudes towards healthy nutrition in terms of the smoking variable among sports science students $(\mathrm{p}<0.05)$. When the effect size value was examined, it was determined that the participation in physical activity $\left(\eta^{2}=.265\right)$ and the attitudes towards healthy nutrition $\left(\eta^{2}=.358\right)$ of smoking and non-smoking participants had a small effect.

Table 7. Comparison of the ASHN and IPAQ scales in terms of the regular exercise variable

\begin{tabular}{cccccccccc} 
Scale & Variable & $\mathrm{N}$ & $\mathrm{M}$ & $\mathrm{SD}$ & $\mathrm{f}$ & $\mathrm{t}$ & $\mathrm{df}$ & $\mathrm{p}$ & $\eta^{2}$ \\
\hline \multirow{2}{*}{ ASHN } & Yes & 249 & 78.46 & 12.41 & \multirow{2}{*}{12.62} & 6.770 & \multirow{2}{*}{390} & $.000 *$ & .735 \\
& No & 143 & 70.33 & 9.51 & & & & & \\
\hline \multirow{2}{*}{ IPAQ } & Yes & 249 & 3453.51 & 1892.01 & 7.815 & 7.844 & \multirow{2}{*}{390} & $.000 *$ & .845 \\
& No & 143 & 1996.22 & 1536.05 & & & & & \\
\hline
\end{tabular}

$* p<0.05$

According to Table 7, a significant difference was found in sports science students' participation in physical activity in terms of the regular exercise variable and healthy nutrition $(p<0.05)$. When the effect size value was examined, it was determined that the physical activity level $\left(\eta^{2}=.845\right)$ and their attitudes towards healthy nutrition $\left(\eta^{2}=.735\right)$ had a moderate effect on the participants who did and did not exercise regularly. 
Table 8. Comparison of the ASHN and IPAQ scales in terms of meals consumed during the day

\begin{tabular}{|c|c|c|c|c|c|c|c|c|c|c|}
\hline \multirow{3}{*}{ Scale } & \multicolumn{2}{|c|}{2} & \multicolumn{2}{|c|}{3} & \multicolumn{2}{|c|}{4} & \multicolumn{2}{|c|}{5} & \multirow{3}{*}{$\mathrm{F}$} & \multirow{3}{*}{$p$} \\
\hline & \multicolumn{2}{|c|}{$n=93$} & \multicolumn{2}{|c|}{$\mathrm{n}=229$} & \multicolumn{2}{|c|}{$\mathrm{n}=51$} & \multicolumn{2}{|c|}{$\mathrm{n}=19$} & & \\
\hline & $\bar{x}$ & Ss & $\bar{x}$ & Ss & $\bar{x}$ & Ss & $\bar{x}$ & Ss & & \\
\hline ASHN & 74.19 & 11.14 & 75.75 & 12.09 & 76.96 & 12.31 & 74.89 & 15.71 & .659 & .578 \\
\hline IPAQ & 2330.97 & 1813.44 & 3023.13 & 1892.48 & 3417.04 & 1881.79 & 3265.11 & 1971.44 & 4.692 & $.003^{*}$ \\
\hline
\end{tabular}

According to Table 8, a significant difference was found in physical activity levels of physical education students in terms of how many meals a day they consume $(F=4.692$; $\mathrm{p}<0.05)$. Tukey HSD post hoc analysis was conducted to determine from which group this difference arises. As a result of the results obtained from this test, a significant difference was determined between the total physical activity levels of the groups consuming 2 meals and 3 and 4 meals. There was no statistically significant difference in physical education students' attitudes towards healthy nutrition in terms of meals consumed during the day $(\mathrm{p}>0.05)$.

Table 9. The relationship between ASHN and IPAQ

\begin{tabular}{cccc} 
& & ASHN & IPAQ \\
\hline \multirow{2}{*}{ ASHN } & $r$ & 1 & $.201^{*}$ \\
& $p$ & - & .000 \\
\hline \multirow{2}{*}{ IPAQ } & $r$ & $.201^{*}$ & 1 \\
& $p$ & .000 & - \\
\hline
\end{tabular}

$* p<0.05$

According to Table 9, a low level of a positive and significant relationship was found between the participants' attitude towards healthy nutrition and their level of participation in physical activity $(\mathrm{p}<0.05)$.

\section{DISCUSSION}

The study was conducted to examine the relationship between sports sciences students' participation in physical activity and their healthy nutrition attitudes. As a result of the analysis conducted on the study group, in the comparison of the students studying at the sports sciences department in terms of gender, smoking and regular exercise variables, a statistically significant difference was found in the level of participation in physical activity in the variable of meals consumed during the day. A low level of a positive significant relationship was found between the participants' attitude towards healthy nutrition and their level of participation in physical activity.

While it was observed that male students in this study participated in more physical activity than female students did, the average scores of female students in their attitudes towards healthy nutrition were higher than among male students. Malkoç et al. [14] examined healthy nutrition attitude habits of university students and reported that female participants showed higher nutritional attitudes than male participants. Arslan et al. [15] found that male students studying at university have higher levels of participation in physical activity than female students. When the literature is examined, there are studies showing that male and female participants have higher participation in physical activity, and female participants have higher nutritional behaviors than male participants [16-20]. Unlike the findings of this study, Aliye Özenoğlu et al. [21] found that men show a higher attitude towards healthy nutrition than women. Gençalp [22] reported that there is no 
significant difference in the gender variable in the participation of university students in nutrition and physical activity. Studies show that there are different results between gender and physical activity and healthy nutrition.

It was determined among sports science students that the participants who do not smoke have higher levels of participation in physical activity and attitudes towards healthy nutrition, compared to the participants who smoke. Vançelik et al. [23], in their study of university students, stated that non-smokers' scores of participation in physical activity and healthy nutrition attitude were higher than among smokers. Unlike these studies, Pirinççi et al. [24] found that there was no difference in physical activity scores between smoking students and non-smokers. Haveman-Nies et al. [25] pointed out the decline in health standards of people with an inactive lifestyle due to smoking. The findings obtained in the light of these results are in parallel with the literature.

A significant difference was found among the sports science students in the comparison of the participants who exercise regularly, their level of participation in physical activity and their attitude towards healthy nutrition. In a study examining the exercise frequency and healthy nutrition attitude levels of those who regularly go to the gym, it was found that the healthy nutrition habits scores were high among the people with high exercise frequency [26]. Çakir [27] reported that university students studying in the health department have a low duration of participation in physical activity; however, they are highly conscious of healthy nutrition but do not eat healthy. In another study examining the frequency of physical activity of 594 university students, it was determined that only 9.9\% of these students were very active [28]. Özkan and Yllmaz [29] found that people who disrupted their weekly exercise lead a more unhealthy life than those who did not interfere with their weekly exercise.

Another finding of the study is that while a significant difference was found in the physical activity levels of the students in terms of meals consumed during the day, no statistically significant difference was found in the comparison of attitudes towards healthy nutrition. It has been determined that $2.5 \%$ of those who exercise regularly in a sports center consume 1 main meal, $26.0 \%$ consume 2 main meals and $39.5 \%$ consume 3 main meals [30]. In another similar study, it was found that $54 \%$ of those who exercise regularly ate 3 main meals a day, and $46 \%$ ate 2 main meals a day. However, it has been determined that individuals' nutritional attitude scores are also high in parallel with regular sports $[26,31]$. Contrary to the findings of this study, there are also studies in the literature reporting that there is no effect on the number of meals consumed and physical activity levels $[19,22]$.

In addition, a low level of a positive significant relationship was found between physical activity levels and their attitudes towards sports nutrition. Gençalp [22] stated that there is a weak, significant positive correlation between university students' physical activity scores and nutritional habits. Yüksel and Akıl [32] found that there is no significant relationship between adolescents' physical activity levels and their nutritional behavior. There are also studies reporting different findings when the literature is examined [19, 21]. Buhaş et al. [33] said that a healthy lifestyle can be related not only to the physical body but also to the mental state.

\section{CONCLUSION}

As a result, in this study, it was determined that students who have high participation in physical activity also have high healthy nutrition attitudes. In the comparison of the variables of gender, smoking and regular exercise, a statistically significant difference 
was found in the attitudes towards participation in physical activity and healthy nutrition of students who received academic education in the field of sports science. While there was no difference in the healthy nutrition scores of the students in the number of meals consumed during the day, it was determined that there was a significant difference in their physical activity levels. In the light of these results, it is thought that gaining healthy nutrition habits with regular physical activity is an important element for the protection and development of health. For this reason, it is recommended to encourage physical activity and develop motivational approaches to healthy nutrition in order to maintain a healthy life.

\section{REFERENCES}

[1] Demir GT, Cicioğlu Hİ. Motivation scale for participation in physical activity (MSPPA): A study of validity and reliability. J Human Sci. 2018;15(4):2479-2492. https://doi.org/10.14687/jhs.v15i4.5585

[2] Çakır E, Şenel Ö. Effect of cold water immersion on performance. European Journal of Physical Education and Sport Science. 2017;3(12):419-428. http://doi.org/10.5281/zenodo.1120423

[3] Baysal A. Beslenme [Nutrition]. Ankara: Hatipoğlu Yayınları; 2009. Turkish.

[4] Condon EM, Crepinsek MK, Fox MK. School meals: Types of food soffered to and consumed by children at lunch and breakfast. J Am Diet Assoc. 2009;109:67-78. https://doi.org/10.1016/j.jada.2008.10.062

[5] Garibağaoğlu M, Budak N, Öner N, Sağlam Ö, Nişli K. Üç farklı üniversitede eğitim gören kız öğrencilerin beslenme durumları ve vücut ağırlıklarının değerlendirilmesi [The evaluation of nutritional status and body weights of female university students attending three different universities]. Sağlık Bilimleri Dergisi. 2006;15(3):173-80. Turkish.

[6] Pekcan G. Beslenme durumunun saptanması [Determination of the nutritional status]. Ankara: Sağlık Bakanlığı Yayınları; 2008. Turkish.

[7] Büyüköztürk Ş. Çakmak EK. Akgün ÖE. Karadeniz Ş. Demirel F. Eğitimde bilimsel araştırma yöntemleri [Scientific research methods in education]. Ankara: Pegem; 2019. Turkish.

[8] Craig CL, Marshall AM, Sjöström AE, et al. International physical activity questionnaire: 12-country reliability and validity. Med Sci Sport Exerc. 2003;35(8):1381-1395. https://doi.org/10.1249/01.MSS.0000078924.61453.FB

[9] Öztürk M. Üniversitede eğitim-öğretim gören öğrencilerde uluslararası fiziksel aktivite anketinin geçerliliği ve güvenirliği ve fiziksel aktivite düzeylerinin belirlenmesi [Determination of the validity and reliability of the international physical activity questionnaire and physical activity levels in students studying at the university]. Master Thesis. Ankara: Hacettepe University, Institute of Health Sciences; 2005. Turkish.

[10] Demir GT, Cicioğlu Hİ. Sağlıklı beslenmeye ilişkin tutum ölçeği (SBİTÖ): geçerlik ve güvenirlik çalışması [Attitude scale for healthy nutrition (ASHN): Validity and reliability study]. Gaziantep Üniversitesi Spor Bilimleri Dergisi. 2019;4(2):256-274.Turkish. https://doi.org/10.31680/gaunjss.559462

[11] Tabachnick BG, Fidell LS. Using multivariate statistics (6th ed.), Boston: Allyn and Bacon; 2013.

[12] Hopkins WG, Marshall SW, Batterham AM, Hanin J. Progressive statistics for studies in sports medicine and exercise science. Med Sci Sports Exerc. 2009;41(1):3-13. https://doi.org/10.1249/MSS.0b013e31818cb278

[13] Büyüköztürk Ş. Sosyal bilimler için veri analizi el kitabı: İstatistik, araştırma deseni, SPSS uygulamaları ve yorum [Data analysis handbook for social sciences: Statistic, research design, SPSS applications and comment]. Baskı (23rd Edition). Ankara: Pegem Akademi; 2017. Turkish. https://doi.org/10.14527/9789756802748

[14] Malkoc N, Yasar OM, Turgut M, et al. Healthy nutrition attitudes of sports science students. Progress in Nutrition. $2020 ; 22(3)$

[15] Arslan SA, Daşkapan A, Çakır B. Üniversite öğrencilerinin beslenme ve fiziksel aktivite alışkanlıklarının belirlenmesi [Specification of nutritional and physical activity habits of university students]. TAF Preventive Medicine Bulletin. 2016;15(3):171-180. Turkish. https://doi.org/10.5455/pmb.1-1436432564

[16] Ree M, Riediger N, Moghadasian MH. Factor saffecting food selection in Canadian population. Eur J Clin Nutr. 2008;62(11):1255-1262. https://doi.org/10.5455/pmb.1-1436432564

[17] Güneş FE, Çalık KBT. The relationship between eating attitude and behaviors with self-esteem of the university students. Anatolian Journal of Psychiatry. 2015;16(6): 397-404. https://doi.org/10.5455/apd.170412

[18] El-Bagoury L, Hassan, A, AbouSeif H. Eating attitudes and barriers to healthy eating and physical activity among a sample of university students in Egypt. Journal of Egyptian Public Health Association. 2017;92(1):29-35. https:// doi.org/10.21608/EPX.2018.6650

[19] Turan, G. Kadın ve erkek paramedik öğrencilerinin fiziksel uygunluk beslenme durumları ve fiziksel aktivite düzeylerinin karşılaştırılması [Comparison of physical fitness, nutritional status and physical activity levels of female and male paramedic students]. İstanbul: Marmara University, Institute of Health Sciences; 2019. Turkish.

[20] Topcu ZG, Kaygisız BB, Demiralp C. How are the physical activity and anxiety levels of the university students affected during the coronavirus (Covid-19) pandemic? Balt J Health Phys Act. 2020;1:33-40. https://doi.org/10.29359/ BJHPA.2020.Suppl.1.04

[21] Özenoğlu A, Gün B, Karadeniz B, et al. Yetişkinlerde beslenme okuryazarlığın sağlıklı beslenmeye ilişkin tutumlar ve beden kütle indeksi ile ilişkisi [The attitudes of nutrition literacy in adults towards healthy nutrition and its relation with body mass index]. Life Sciences. 2021;16(1):1-18. Turkish. https://doi.org/10.12739/NWSA.2021.16.1.4B0037

[22] Gençalp DK. Covid-19 salgını döneminde ilk ve acil yardım öğrencilerinin beslenme alışkanlıkları ve fiziksel aktivite durumlarının değerlendirilmesi [Evaluation of dietary habits and physical activity status of first and emergency aid students in covid-19 outbreak period]. Paramedik ve Acil Sağlık Hizmetleri Dergisi. 2020;1(1):1-15. Turkish. 
[23] Vançelik S, Önal SG, Güraksın A, Beyhun E. Üniversite öğrencilerinin beslenme bilgi ve alışkanlıkları ile ilişkili faktörler [Related Factors with Nutritional Habits and Nutrition Knowledge of University Students]. TSK Koruyucu Hekimlik Bülteni. 2007;6(4):242-248. Turkish.

[24] Pirinççi CŞ, Cihan E, Yıldırım NÜ. Üniversite öğrencilerinde fiziksel aktivite düzeyinin yaşam kalitesi, kronik hastalık varlığı, sigara kullanımı ve akademik başarıyla olan ilişkisi [The relationship between physical activity level and quality of life, presence of chronic disease, smoking and academic success in university students]. KTO Karatay Üniversitesi Sağllk Bilimleri Dergisi. 2020;1(1):15-23. Turkish.

[25] Haveman-Nies A, De Groot LC, Van Staveren WA. Relation of dietary quality, physical activity, and smoking habits to 10-year changes in health status in older Europeans in the SENECA study. Am J Public Health. 2003;93(2):318-323. https://doi.org/10.2105/AJPH.93.2.318

[26] Karaağaç G. Spor salonlarına giden bireylerin sağlıklı beslenme tutumları ve sosyal görünüş kaygı düzeylerinin belirlenmesi [Healthy eating attitudes and determination of social appearance anxiety levels of individuals participating in gym physical activity]. Kars: Kafkas University, Institute of Health Sciences; 2020. Turkish.

[27] Çakir E. The examination of exercise addiction levels of university students studying in health field. Journal of Education and Training Studies. 2019;7(3):177-181. https://doi.org/10.11114/jets.v7i3.4096

[28] Burke SM, Carron AV, Eys MA. Physical activity context and university student's propensity to meet the guidelines Centers for Disease Control and Prevention/American College of Sports Medicine. Med Sci Monit. 2005;11(4):171176. PMID: 15795696

[29] Özkan S, Yılmaz E. Hastanede çalışan hemşirelerin sağlıklı yaşam biçimi davranışları [The health-promoting lifestyles of nurses working at hospital]. Fırat Sağllk Hizmetleri Dergisi. 2008;3(7):90-104. Turkish.

[30] Halvarsson K, Lunner K, Westerberg J, Anteson F, Sjödén PO. A longitudinal study of the development of dieting among 7-17 year old Swedish girls. Int J Eat Disord. 2002;31(1):32-42. https://doi.org/10.1002/eat.10004

[31] Bully P, Elosua P. Changes in body dissatisfaction relative to gender and age: The modulating character of BMI. The Spanish J Physiol. 2011;14(1):313-322. https://doi.org/10.5209/rev_SJOP.2011.v14.n1.28

[32] Yüksel E, Akıl M. Adölesanların fiziksel aktivite seviyeleri ile obezite farkındalık düzeyleri ve beslenme davranışlarının incelenmesi [Investigation of the correlation between the physical activity levels of adolescents and their awareness about obesity and nutritional behaviors]. Niğde Ömer Halisdemir University Journal of Physical Education and Sports Sciences. 2019;13(3):185-193. Turkish.

[33] Buhaş R. Săveanu S, Bacter C. Physical activity and other health related behaviors in adults from Oradea, Romania. Facts and social factors. Balt J Health Phys Act. 2020;12:36-45. https://doi.org/10.29359/BJHPA.12.Spec.Iss1.05 